\title{
Isolation, Partial Purification and Characterization of L-Asparaginase from Hedgehog Serum
}

\author{
Ekpa Emmanuel ${ }^{1,2 *}$, Nzelibe $\mathrm{HC}^{1}$ and Onyike $\mathrm{E}^{1}$ \\ ${ }^{1}$ Department of Biochemisttry, Ahmadu Bello University, Zaria, Nigeria \\ ${ }^{2}$ Department of Biosciences, Salem University Lokoja, Nigeria
}

\begin{abstract}
The need to further explore other sources of therapy for leukemias prompted this current work. It's already known that L-asparaginase possess a lot of potentials in the treatment of cancers of the white blood cell but the sources of these enzyme and its properties determines the efficacy of this drug. Generally, for an asparaginase to be ideally suited for use in anti-tumour therapy, it had to satisfy a variety of criteria. The organism that is selected should produce the asparaginase in high quantity or yield, and it should be capable of being isolated from simple mammalian sources. The procedures developed for purification of the enzyme should be as rapid and simplified as possible. The purified enzyme should have long term stability on storage, maximal activity at a physiological $\mathrm{pH}$, and a Km for substrate below the concentration of the substrate in the blood. Therefore the aim of this present research was to partially purify and characterize this enzyme from Hedgehog serum in order to compare its anti-leukemic potentials with those from documented literature for possible future medical application. L-asparaginase was isolated and partially purified from Hedgehog serum which is also known to be a reservoir of many other useful proteins including anti venoms using a four step profile of ammonium sulphate fractionation, dialysis, and ion exchange and gel filtration chromatography. The enzyme gave an overall yield of $77.58 \%$, optimum $\mathrm{pH}$ and temperature of 7.8 and $39^{\circ} \mathrm{C}$ respectively, and a $\mathrm{Km}$ of $0.0125 \mathrm{mM}$. Gel filtration gave an approximate molecular weight of $139,000 \mathrm{Da}$, while SDS PAGE indicated a subunit molecular weight of 36,000 and 34,600 Da respectively. The enzyme also catalyses the hydrolysis of glutamine though slightly. $\mathrm{Mg}^{2+}$ and $\mathrm{Zn}^{2+}$ serve as activators for Hedgehog serum L-asparaginase, while inhibition from heavy ions like $\mathrm{Hg}^{2+}$ was also observed. This work shows that mammalian sources of this enzyme could be more preferable for treatment of asparagine dependent tumours in time to come.
\end{abstract}

Keywords: L-asparaginase; Tumor therapy; Leukemia; Hedgehog

\section{Introduction}

L-asparaginases are enzymes that catalyze the hydrolysis of $\mathrm{L}$-asparagine to L-aspartate and ammonia. They are also known as L-asparagine amido hydrolases (E.C. 3.5.1.1). The enzymes are present in many animal tissues, bacteria, plants, and in the serum of certain rodents and lower mammals but not of man. Asparagine is one of the twenty common natural amino acids on earth. It is a non-essential amino acid, since it can be synthesized by the body cells. Increasing interest in these enzymes stemmed from their identification by Broome in 1961 as anti leukemic agents in guinea pig serum. Following the discovery that the E-coli enzyme also had the anti-tumour activity by Mashburn and Wriston, work then preceded in several laboratories and other research centres leading to several clinical trials (Abuchowski et al.). L-asparaginases have been isolated from a number of sources which include; Erwinia Carotovora, Serratia Marcescens, and a host of other microbial and mammalian sources. Though the activity of this enzyme has been reported in many lower mammals, no such literature has been found for hedgehog serum till date.

L-asparaginases from Erwinia and E. coli have been reported for many years as effective drugs in the treatment of acute lymphoblastic leukemia (certain type of cancer). The Drugs are not however devoid of some serious side effects. Therefore,finding safer and cheaper sources of these enzyme is of paramount importance. L-asparaginases from bacterial species have been known to cause adverse allergic reactions, anaphylaxis and hypersensitivity in the long term, despite their high therapeutic (anti-tumour) properties. However, these immunological problems highlighted above can be circumvented by sequential therapy with serologically unrelated asparaginases [1]. This has prompted further research with a view to finding a variety of asparaginases from other local sources like fungi, basidiomycetes, and small mammals like hedgehogs. Most of the Microbial sources of L-asparaginases are not amenable to isolation without the presence of so many interfering proteins thereby limiting the amount of useful enzyme preparation required for industrial/medical applications.

Mammalian and other fungal sources of L-asparaginases have been studied less thoroughly, as such more work is required on them and their anti-tumour potentials. There is also need to screen the enzyme from these mammalian sources in order to compare their properties with those documented in literature. In addition, producing mammalian L-asparaginases from sources similar to those of guinea pigs (with good anti-tumour activity) is highly required as a target for future cancer therapy. L-asparagine plays a very significant role in the metabolism of leukemic (tumour) cells. This is because, these cells require asparagines for protein biosynthesis and therefore when such cells are starved of asparagines, they get destroyed automatically. In addition, most cells are known to use the enzyme asparagines synthetase to make their own asparagines [2]. While most cells are able to make their own supplies of asparagines and do not need to obtain it in their diet, some blood

*Corresponding authors: Ekpa Emmanuel, Department of Biochemisttry, Ahmadu Bello University, Zaria, Nigeria, Tel: (+273) 7036135834; E-mail: emmeks@yahoo.co.uk

Received August 14, 2015; Accepted October 01, 2015; Published October 08 2015

Citation: Emmanuel E, Nzelibe HC, Onyike E (2015) Isolation, Partial Purification and Characterization of L-Asparaginase from Hedgehog Serum. J Microb Biochem Technol 7: 404-409. doi:10.4172/1948-5948.1000246

Copyright: (c) 2015 Emmanuel E, et al. This is an open-access article distributed under the terms of the Creative Commons Attribution License, which permits unrestricted use, distribution, and reproduction in any medium, provided the original author and source are credited. 
cells, however, rely instead on the blood for their supply. This is the whole aim of L-asparaginase therapy considering the fast rate of cell division occurring in cancerous cells. In an attempt to address some of the salient issues raised above, the aim of this work is to extract the enzyme from a mammalian source so as to determine if they actually possess L-asparaginase activity when compared to those documented in literature and also to partially purify and characterize the enzyme from Hedgehog serum so as to find its anti-tumour potentials for possible future clinical trials.

\section{Materials and Method}

\section{Hedgehog serum}

Hedgehogs were hunted from the wild within Jaji-Igabi Local Government Area of Kaduna state. They were then slaughtered from the jugular vein and fresh blood collected into already prepared eppendorf tubes and allowed to clot on their own. Serum was subsequently taken into the Lab for further analysis.

\section{Determination of L-asparaginase activity}

Enzyme activity was determined using the method of Majundar et al. [3] as modified by the "Sigma quality control test procedure." The assay system consisted of $0.1 \mathrm{ml}$ of enzyme extract, $0.1 \mathrm{ml}$ of 0.01 $\mathrm{M}$ of L-asparagine, and $1 \mathrm{ml}$ of $0.05 \mathrm{M}$ tris $\mathrm{HCl}$ buffer. All these were pipetted into a test tube and placed in a water bath maintained at $37^{\circ} \mathrm{C}$ for 30 minutes. After the incubation, $1.5 \mathrm{ml}$ of Tri Chloro acetic acid (TCA) was added to stop the reaction. These were then centrifuged for 2 minutes and the supernatant collected in a clean tube. Ammonia released by the catalysis of L-asparagine was estimated by Nessler's method. To $1 \mathrm{ml}$ of the supernatant, $4.3 \mathrm{ml}$ of distilled water and $0.5 \mathrm{ml}$ of Nessler's reagent were added. This mixture was allowed to stay for another 2 minutes in a water bath at the same temperature. The colour intensity was measured at $436 \mathrm{~nm}$ using a Unicam Alpha spectrophotometer.Absorption was then compared to a standard curve of ammonium sulphate earlier determined in order to find the concentration of ammonia released. One enzyme unit $(1 \mathrm{U})$ is defined as the amount of enzyme required to liberate one micromole of ammonia per minutes at $37^{\circ} \mathrm{C}$ under specified condition. Total protein was determined by Biuret method according to Plummer using Bovine serum Albumin.

$$
\text { units } / m g=\frac{\mu \text { mole of } \mathrm{NH}_{3} \text { released }}{\text { Time of reaction } \times \text { mg of enzyme in reaction }}
$$

\section{Enzyme purification assay}

The purification assay for the enzyme was according to Borek and Lubkowski [4].The following purification steps were carried out.

\section{Ammonium sulphate fractionation/dialysis}

The crude enzyme extract was precipitated out using different levels of ammonium sulphate saturation between $35-80 \%$.The pellets were collected after each saturation interval by centrifugation at 10,000 g for 20 minutes at $4^{\circ} \mathrm{C}$, and suspended in $0.01 \mathrm{M}$ phosphate buffer $\mathrm{pH}$ 8.5.At each of this stage, enzyme activity and protein concentration determined. The dissolved pellets were further subjected to dialysis for 48 hours in a dialysis bag kept at $4^{\circ} \mathrm{C}$ and then loaded onto DE-52 ion exchanger column $(20 \times 25 \mathrm{~cm})$.

\section{DEAE cellulose chromatography (ion exchange chromotography)/gel filtration chromatography using sephadex G-75}

DEAE cellulose chromatographic column pre-equilibrated with $0.01 \mathrm{M}$ tris $\mathrm{HCl}(\mathrm{pH} 8.6)$ containing $0.01 \mathrm{M} \mathrm{KCl}$ was loaded onto a column $(1.5 \times 20)$ with $5 \mathrm{ml}$ of the crude enzyme and the flow monitored and fractions collected. The column was washed with 5-10 volume of $0.01 \mathrm{M}$ tris $\mathrm{HCl}+0.5 \mathrm{M} \mathrm{KCl}$ and eluted with $0.01 \mathrm{M}$ tris $\mathrm{Hcl}$. About 22 fractions were collected and assayed for L-asparaginase activity. Also, gel filtration chromatography with sephadex G-75 was performed for further purification and also to determine molecular weight. The column was eluted with the same buffer. All the purification was monitored by UV-Spectrophotometer.

\section{SDS-page purification}

Fractions containing high specific activity were pooled together and subsequently subjected to further purification using SDS-PAGE. These fractions were loaded onto a column packed with sephadex G-75 pre-equilibrated with $0.05 \mathrm{M}$ phosphate buffer ( $\mathrm{pH}$ 6.8) and the active eluates analyzed on $12 \%$ reducing SDS-PAGE. They were thereafter treated by washing with bromophenol blue and visualized with comassie brilliant blue. Gels were stained together with standard protein markers for molecular weight determination. After the electrophoresis, relative mobilities were calculated for each of the proteins. Relative mobilities (Rf) were obtained by measuring the distance migrated by the tracker dye. The molecular weight of the partially purified enzyme was calculated by proportion.

\section{Optimum temperature}

Activity measurements of the enzyme were carried at different temperature $\left(0^{\circ} \mathrm{C}, 10^{\circ} \mathrm{C}, 20^{\circ} \mathrm{C}, 30^{\circ} \mathrm{C}, 40^{\circ} \mathrm{C}, 50^{\circ} \mathrm{C}, 60^{\circ} \mathrm{C}, 70^{\circ} \mathrm{C}\right.$, etc. $)$. The enzyme activity was determined as described in section 3.2.0 at these temperatures and the rate of activity was plotted against temperature so as to find the optimal temperature.

\section{Optimum pH}

The optimum $\mathrm{pH}$ determination of the enzyme was carried out in different buffers with varying $\mathrm{pH}$ range (3.5-9.0). The enzyme activity rate at each $\mathrm{pH}$ was recorded and a plot of $\mathrm{pH}$ against enzyme activity was made to determine the optimum $\mathrm{pH}$ with varying $\mathrm{L}$-asparagine.

\section{$\mathrm{K}_{\mathrm{m}}$ and $\mathrm{V}_{\text {max }}$ determination}

Different concentrations of the substrate L-asparagine were prepared in the following order $(2.5 \mathrm{mM}-10 \mathrm{mM})$. The absorbances were determined at each of the above concentrations of the substrate at $436 \mathrm{~nm}$. Thereafter, inverse of the activity rate was plotted against substrate concentration in order to determine the $\mathrm{Km}$ and Vmax respectively.

\section{Effect of cations on enzyme activity}

About $1.0 \mathrm{ml}$ of the enzyme and $0.2 \mathrm{ml}$ of $0.02 \mathrm{M}$ of these cations $\left(\mathrm{MgCl}_{2}, \mathrm{KCl}_{2}, \mathrm{CaCl}_{2}, \mathrm{FeCl}_{2}\right.$, and $\left.\mathrm{HgCl}_{2}\right)$ were incubated at $37^{\circ} \mathrm{C}$ for $3-5$ minutes and the activity determined as described before.

\section{Effect of inhibitors on L-asparaginase activity}

L-aspartate, L-glutamate, and L-Norvaline (specific inhibitor) 
were used as inhibitors in this work. Aliquots of the enzyme $(1 \mathrm{ml})$ and $0.2 \mathrm{ml}$ of varying concentration of the inhibitors were incubated with substrate of varying concentrations $(0.01-0.12 \mathrm{M})$. The activity were determined as previously described.

\section{Results and Discussion}

The effect of temperature on L- asparaginase activity is shown in Figure 1.Optimum temperature was recorded at $39^{\circ} \mathrm{C}$. This is principally attributed to the fact that L-asparaginases in most cases act within the normal temperature range of man [5]. In addition, most medically active asparaginases possess optimum temperature between $35-40^{\circ} \mathrm{C}$ [6]. Generally, the effect of temperature on Enzyme-catalyzed reactions is extremely complex. This is because a change in the observed rate may be due to a variety of causes like stability of the enzyme protein, $\mathrm{pH}$ of the buffer system, $\mathrm{kM}$, and a host of other factors. The effect of $\mathrm{pH}$ on enzyme activity is shown in Figure 2 . The $\mathrm{pH}$ optimum for the partially purified Hedgehog serum L-asparaginase is 7.8. This is in agreement with a number of $\mathrm{pH}$ optimums from various $\mathrm{L}$-asparaginases from diverse sources (Table 1). Most L-asparaginases having antitumour activities have optimum pH's of between 7.5-8.5 as reported by Swain et al. [7]. Another reason for these observed optimum $\mathrm{pH}$ values are due to the fact that medically useful asparaginases normally act within physiological $\mathrm{pH}$, i.e., around the normal $\mathrm{pH}$ of blood. Effect of substrate Concentration on enzyme activity is shown in Figure 1.

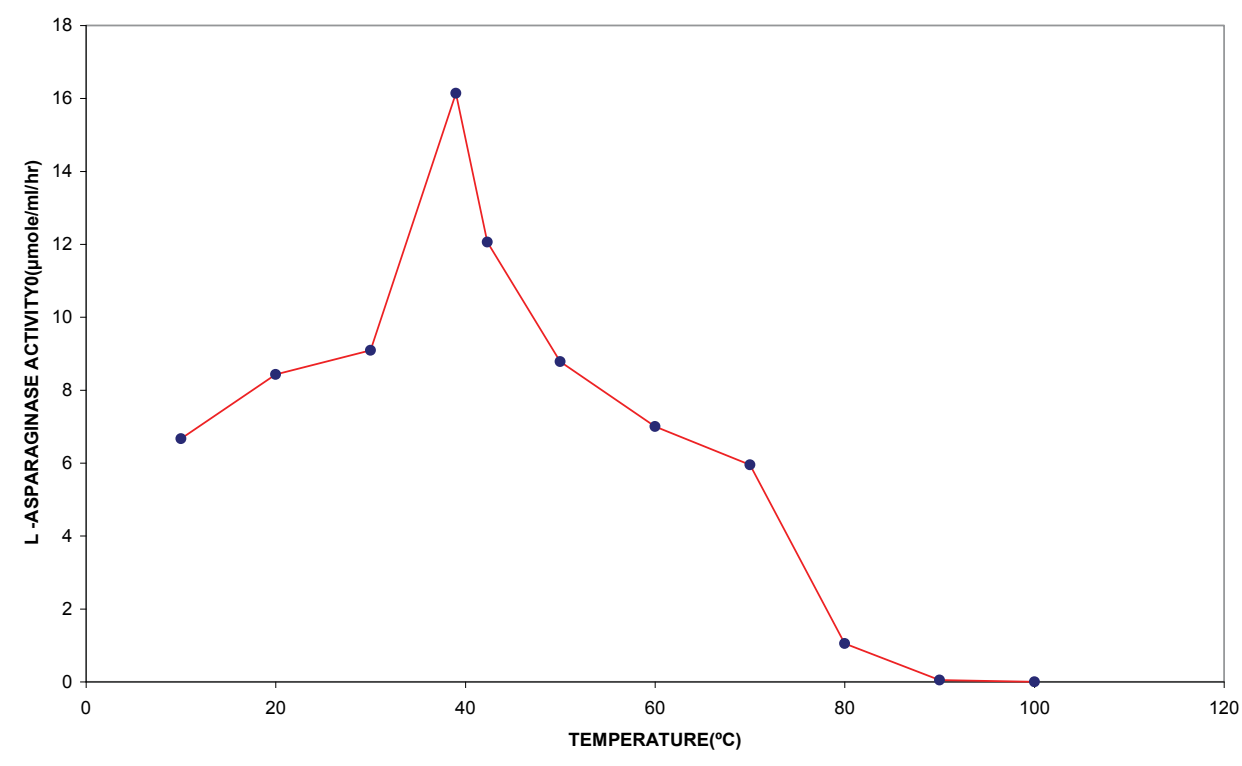

Figure 1: Effect of temperature on $\mathrm{L}$-asparaginase activity.

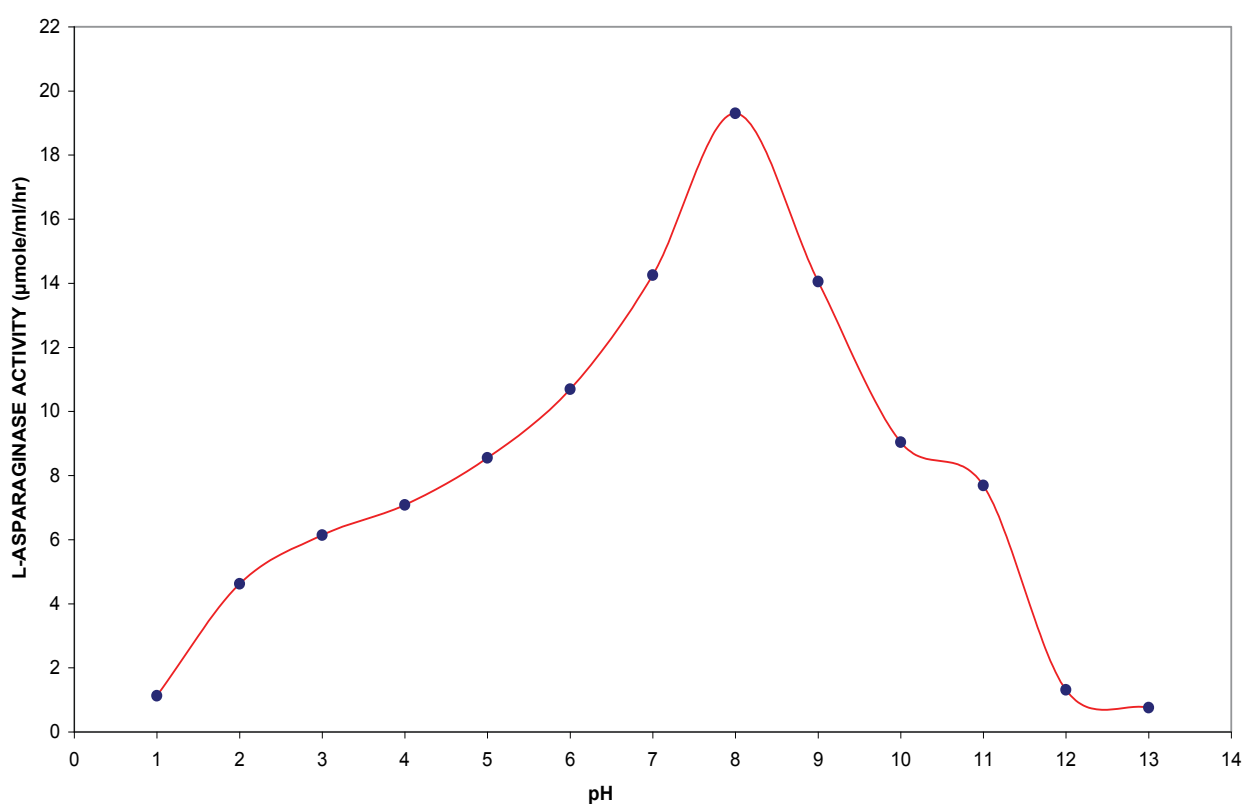

Figure 2: Effect of $\mathrm{pH}$ on L-asparaginase activity. 
Citation: Emmanuel E, Nzelibe HC, Onyike E (2015) Isolation, Partial Purification and Characterization of L-Asparaginase from Hedgehog Serum. J Microb Biochem Technol 7: 404-409. doi:10.4172/1948-5948.1000246

The highest activity was recorded at a substrate concentration of 0.01 $\mathrm{mM}$.When the Lineweaver Burk's plot of the determination was done (Figure 2), $\mathrm{Km}$ and $\mathrm{Vmax}$ were gotten as $0.0125 \mathrm{mM}$ and $1.6 \mathrm{~mole} / \mathrm{M}$ respectively. These values are in line with those of other very useful chemotherapeutic L-asparaginases. Generally, asparagine does not become severely limiting for protein synthesis until the concentration is reduced to $0.01 \mathrm{mM}$ or below and consequently, for asparagines to be an effective antitumour agent, the enzyme must have a high substrate affinity. The effect of divalent cations is shown in Figure 2. Metals generally serve some specific roles in enzyme chemistry, they aid in the catalytic efficiency of the enzymes in which they are found (Co-factors). In this experiment, $\mathrm{MgCl}_{2}, \mathrm{ZnCl}_{2}$ and $\mathrm{CaCl}_{2}$ were found to have some activating functions in the activity of Hedgehog serum $\mathrm{L}$-asparaginase. This is in consonance with many asparaginases from bacterial sources [8-11]. $\mathrm{HgCl}_{2}$ and $\mathrm{FeCl}_{2}$ being heavy metals showed deactivating functions as expected with most heavy metals serving as co-factors.
Elution profile of partially purified Hedgehog serum L-asparaginase is shown in Figure 3.Two very conspicuous peaks were observed. The first major peak of fractions $4-6$ gave specific activity of $42.78 \mu \mathrm{mole} / \mathrm{m} /$ $\mathrm{hr} / \mathrm{mg}$. Second peak (Fraction 7-10) gave almost similar values like the first suggesting that the DEAE cellulose-52 purification step was not conclusive enough. In all, about 17 fractions were collected and fractions with higher specific activities were collected, pooled together and ran with a sephadex G-75.Elution using sephadex G-75 gave a specific activity of $84.76 \mu \mathrm{mole} / \mathrm{ml} / \mathrm{hr} / \mathrm{mg}$ (Table 2, Figure 2).The purification fold rose up to 5.61 and yield was recorded as $61.00 \%$. About 24 fractions were collected for the gel filtration chromatography. When these purifications were compared with those other screened organism including E. coli (which served as reference). It was observed that Hedgehog serum L-asparaginase had a better yield of enzyme than all of them. (Table 1 and 2).This might not be far from the simple fact that mammalian sources of asparaginases possess higher yield in terms of quantity typified by yield from Guinea pig serum. Also, Hedgehog

\begin{tabular}{|c|c|c|c|c|c|}
\hline & TOTAL PROTEIN (mg/ml) & $\begin{array}{c}\text { TOTAL ACTIVITY } \\
\text { hr) }\end{array}$ & $\begin{array}{l}\text { SPECIFIC ACTIVITY ( } \mu \mathrm{mole} / \mathrm{ml} / \mathrm{hr} / \mathrm{mg} \\
\text { protein) }\end{array}$ & $\begin{array}{l}\text { PURIFICATION } \\
\text { FOLD }\end{array}$ & YIELD (\%) \\
\hline Crude & 1.14 & 14.01 & 12.29 & 1.00 & 100 \\
\hline $\begin{array}{l}\left(\mathrm{NH}_{4}\right)_{2} \mathrm{SO}_{4} \\
\text { Precipitation }\end{array}$ & 1.05 & 13.63 & 12.98 & 1.06 & 97.29 \\
\hline Dialysis & 0.75 & 12.87 & 16.93 & 1.38 & 91.86 \\
\hline DEAE-52 & 0.23 & 12.04 & 52.35 & 4.26 & 85.94 \\
\hline SEPHADEX G-75 & 0.15 & 11.24 & 74.93 & 6.10 & 80.23 \\
\hline
\end{tabular}

Table 1: Purification profile of partially purified L-asparaginase from Hedgehog serum.

\begin{tabular}{|c|c|c|c|c|c|c|c|}
\hline Source & Mol wt. & Subunits & $\mathrm{pH}$ optimum & $\mathrm{Km}(\mathrm{mM})$ & Glutaminase activity & Blood clearance time(hrs) & Anti-tumour activity \\
\hline Guinea pig serum & $\begin{array}{l}138,000 \\
133,000\end{array}$ & N.D & $7.5-8.5$ & 0.072 & Nil & 26 & + \\
\hline E. coli & 130,000 & 4 & 4.9 & 0.013 & Slight & 4.2 & + \\
\hline Fusarium trinctum & 165,000 & N.D & 5.18 & 0.012 & Nil & Very rapid & - \\
\hline Green chillies & 120,000 & N.D & 8.5 & 3.3 & Yes & 4 & + \\
\hline Hedgehog serum* & $\begin{array}{c}139,000 \\
34,600\end{array}$ & 2 & 7.8 & 0.0125 & Slight & $9.8-16.4$ & + \\
\hline
\end{tabular}

Table 2: Properties of L-asparaginase having anti-tumour activity from different sources as compared with that from hedgehog serum.

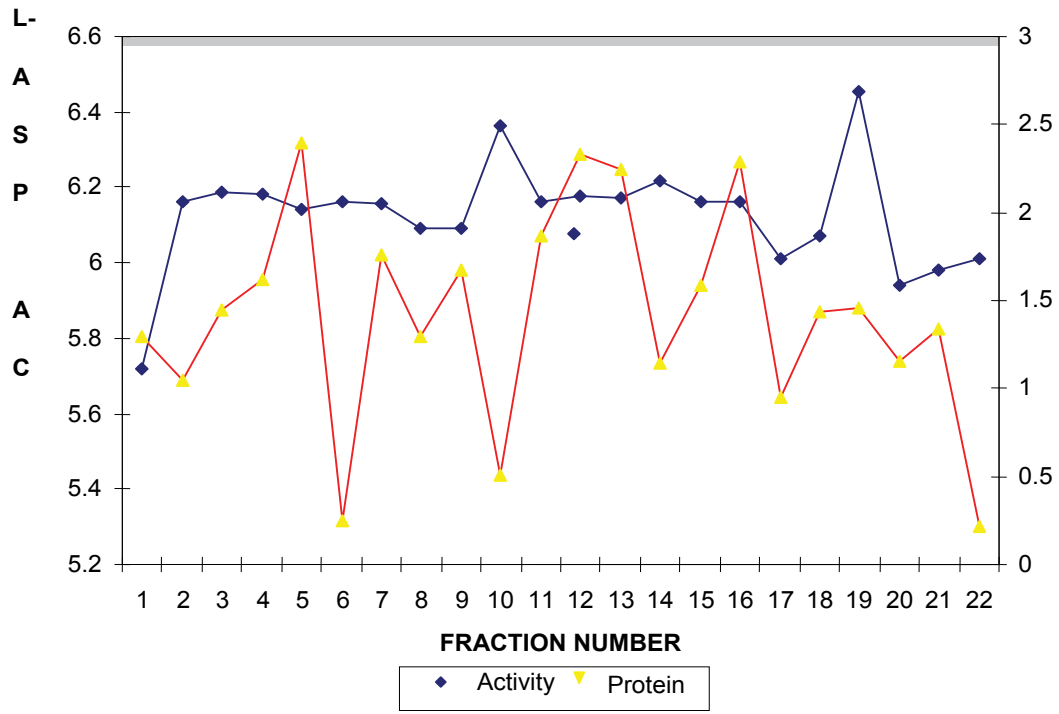

Figure 3: Elution profile of crude hedgehog serum L-asparaginase. 
Citation: Emmanuel E, Nzelibe HC, Onyike E (2015) Isolation, Partial Purification and Characterization of L-Asparaginase from Hedgehog Serum. J Microb Biochem Technol 7: 404-409. doi:10.4172/1948-5948.1000246

serum is known to be a reservoir of many useful proteins including anti venoms probably due to the harsh kind of habitat where Hedgehogs normally occupy in the ecosystem. Molecular weight determinations using the sephadex G-50 gave an average value of 139,000 Da for the partially purified Hegehog L-asparaginase. While SDS PAGE indicated subunits of $34.6 \mathrm{KDa}$ and $36 \mathrm{KDa}$ respectively (Figure 4 and 5). These values are consistent with most tumour inhibitory asparaginases with molecular weight between 120,000 and 150,000 Da. Molecular weight variations is one of the characteristic of active anti-tumour $\mathrm{L}$-asparaginases. Furthermore, this molecular weight is very close to that of the Guinea pig serum L-asparaginase giving credence to the assertion that serum from lower mammals could be one of the future target sources of this important enzyme.

Generally, for an asparaginase to be ideally suited for use in antineoplastic therapy, it had to satisfy a variety of criteria. The organism that is selected should produce the asparaginase in high quantity or yield, and it should be capable of being grown in large amount on a simple and inexpensive medium if it's a microorganism. The procedures developed for purification of the enzyme should be as rapid and simplified as possible, providing pure enzyme in high yield. The purified enzyme should have long term stability on storage, maximal activity at a physiological $\mathrm{pH}$, and a $\mathrm{Km}$ for substrate below

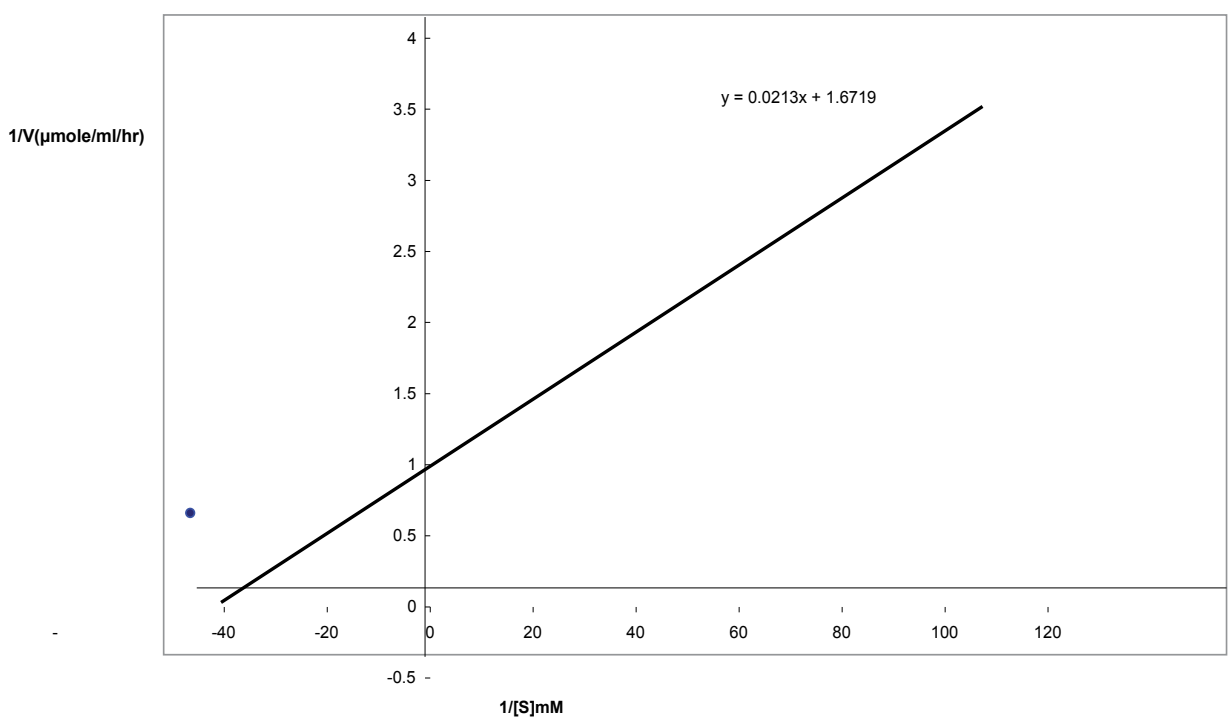

Figure 4: Line weaver burk's plot for hedgehog L-asparaginase activity.

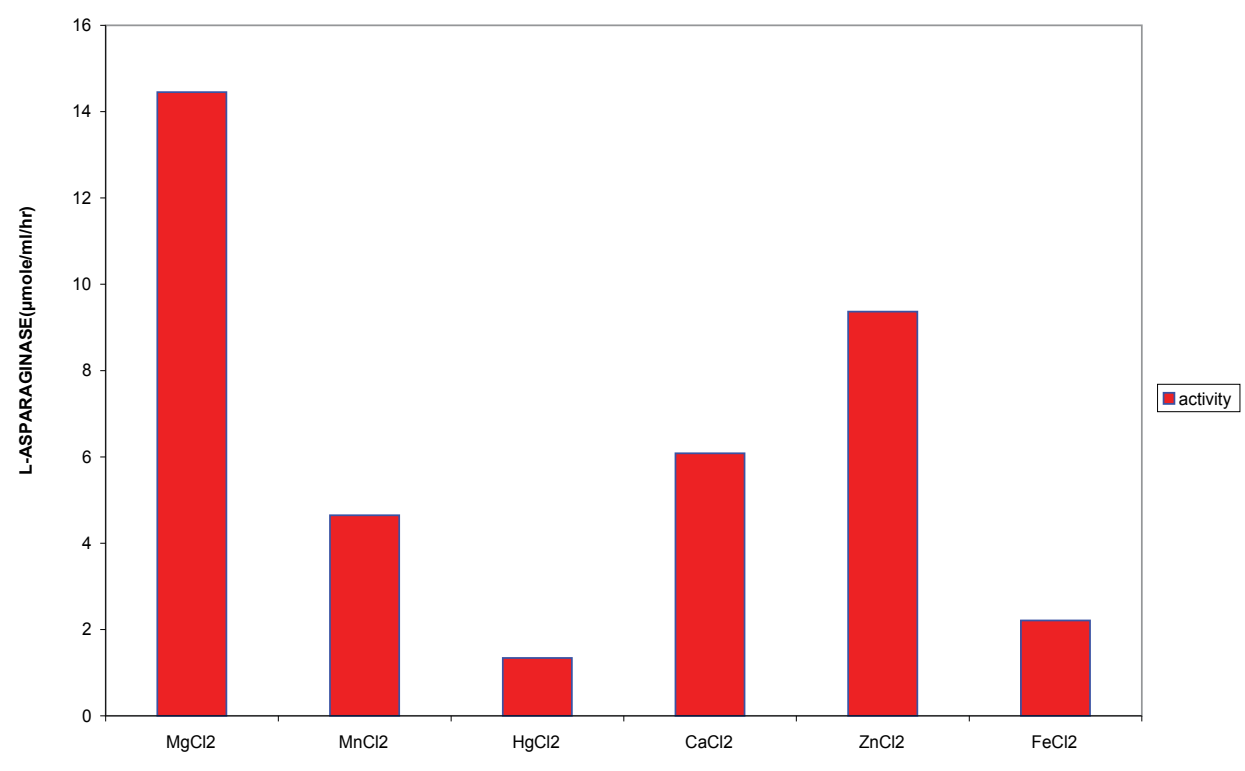

Figure 5: Effect of cations on L-asparaginase activity. 
Citation: Emmanuel E, Nzelibe HC, Onyike E (2015) Isolation, Partial Purification and Characterization of L-Asparaginase from Hedgehog Serum. J Microb Biochem Technol 7: 404-409. doi:10.4172/1948-5948.1000246

the concentration of the substrate in the blood. In conclusion, this work has shown that mammalian sources of this enzyme could serve as great therapy for asparagine dependent tumours.

\section{References}

1. Dodson G, Wlodawer A (1998) Catalytic triads and their relatives. Trends Biochem Sci 23: 347-352

2. Kil JO, Kim GN, Park I (1995) Extraction of extracellular L-asparaginase from Candida utilis. Biosci Biotechnol Biochem 59: 749-750.

3. Mazumdar UK, Gupta M, Maiti S, Mukherjee D (1997) Antitumor activity of Hygrophila spinosa on Ehrlich ascites carcinoma and sarcoma-180 induced mice. Indian J Exp Biol 35: 473-477.

4. Borek D (2001) Structure and biochemical studies of aparaginases, Mickiewicz University, Poznan.

5. Aghaiypour K, Wlodawer A, Lubkowski J (2001) Do bacterial L-asparaginases utilize a catalytic triad Thr-Tyr-Glu? Biochim Biophys Acta 1550: 117-128.

6. Aghaiypour K, Wlodawer A, Lubkowski J (2001) "Structure basis for the activity and substrate specificity of Erwinia chrysanthemic L-asparaginase." Biochemistry 15: 5655-5664.

7. Swain AL, Jaskolski M, Housser D, Rao JK, Wlodawer A (1993) Crystal structure of Escherichia coli I - asparaginase, an enzyme used in cancer therapy. Pro Natl Acad sci 90: 1474-1478.

8. Villa P, Corada M, Bartosek (1986) I-asparaginase effects on inhibition of protein synthesis and lowering of the glutamine content in cuture hepatocytes. toxicology letters 32: 225-241.

9. Zhang N, Clarke F, Di Trapani G, Keough D, Beacham (1995) "Guinea pig serum L-asparaginase: Purification, and immunological relationship to liver L-asparaginase and serum L-asparaganiase in other mammals." Comp Biochem physiol B Biochem Mol Biol 112: 607-612.

10. Abuchowski A, Kazo GM, Verhoest CR Jr, Van Es T, Kafkewitz D, et al. (1984) Cancer therapy with chemically modified enzymes. I. Antitumor properties of polyethylene glycol-asparaginase conjugates. Cancer Biochem Biophys 7 : polyethylen.

11. Tumbula DL, Becker HD, Chang WZ, Söll D (2000) Domain-specific recruitment of amide amino acids for protein synthesis. Nature 407: 106-110. 